\title{
ANALISIS SKALA PRIORITAS PENGGUNAAN DANA DESA DI KABUPATEN SEMARANG, DEMAK DAN KENDAL
}

\section{PRIORITY SCALE ANALYSIS OF VILLAGE FUND USAGE IN SEMARANG, DEMAK AND KENDAL REGENCY}

\author{
Arief Sulasdiono ${ }^{1}$, Ray Septianis Kartika ${ }^{2}$ \\ ${ }^{1,2}$ Badan Penelitian dan Pengembangan Kemendagri \\ Jl. Kramat Raya No.132 Jakarta Pusat, Jakarta, Indonesia \\ e-mail: raseka1979@gmail.com
}

Diserahkan: 11/12/2020, Diperbaiki: 18/03/2021, Disetujui: 19/03/2021

DOI: $10.47441 / j k p . v 16 i 1.141$

\begin{abstract}
Abstrak
Skala prioritas dalam penggunaan dana desa merupakan upaya memperhitungkan kebutuhan desa ketika proses perencanaan maupun saat penggunaan anggaran. Implementasinya harus relevan dengan kebutuhan masyarakat. Penentuan skala prioritas akan menghadapi permasalahan jika mendapatkan intervensi kepala daerah. Kajian ini bertujuan untuk mengidentifikasi skala prioritas penggunaan desa sesuai dengan Peraturan Pemerintah No. 60 Tahun 2014 tentang Dana Desa. Penelitian ini berjenis deskriptif kualitatif. Lokus penelitian adalah Kabupaten Kendal, Kabupaten Demak, dan Kabupaten Semarang. Data diambil melalui wawancara dan Focus Group Discussion (FGD). Hasil kajian menunjukan bahwa skala prioritas di Kabupaten Semarang diarahkan untuk pembangunan fisik; skala prioritas di Kabupaten Demak diarahkan untuk pemerintahan desa, pelaksanaan pembangunan desa, pembinaan kemasyarakatan, dan pemberdayaan masyarakat desa; sedangkan skala prioritas kabupaten Kendal, yaitu untuk pelaksanaan pembangunan desa, dan pembinaan kemasyarakatan desa. Penentuan skala prioritas tersebut didasarkan pada kebutuhan dan permasalahan di masing-masing daerah. Rekomendasi kajian ini adalah perlu adanya identifikasi kebutuhan program berdasarkan pemetaan masalah yang ada di daerah setempat, perlu dilakukan pengawasan untuk mensinkronkan APBDesa dengan skala prioritas penggunaan dana desa sekaligus menindaklanjuti hasil laporan pengawasan tersebut, dan pelibatan kader desa untuk menjadi tim pengawas dana desa, termasuk usulan dana desa yang tidak sesuai dengan skala prioritas.
\end{abstract}

Kata Kunci: Skala Prioritas, Dana Desa, Pembangunan Desa.

\section{Abstract}

The priority scale in the use of village funds is an effort to take into account village needs during the planning process and when the budget is used. Its implementation must be relevant to community needs. Determining the priority scale will face problems if it gets intervention from the regional head. This study aims to identify the priority scale for village use by Government Regulation Number 60 of 2014 concerning Village Funds. This research is a descriptive qualitative type. The research focuses are Kendal, Demak, and Semarang Regency. Data were collected through interviews and Focus Group Discussions (FGD). The results of the study show that the determination of the priority scale is based on the needs and problems in each region. Semarang Regency is directed towards physical development; Demak Regency is directed at village governance, implementation of village development, community development, and empowerment of village communities; while the Kendal priority scale were village community development. This study recommends that there is a need for identification of program needs based on mapping of existing problems in the local area, it is necessary to carry out supervision to synchronize the APBDesa 
with the priority scale for the use of village funds as well as to follow up on the results of the monitoring report, and to include village cadres in the team that oversees the suitability of village fund proposals against priority scale and use of village funds.

Keywords: Priority Scale, Village Fund, Village Development

\section{PENDAHULUAN}

Realisasi dana desa kerap kali menjadi persoalan ketika tidak termanfaatkan dengan baik dan tepat. Alokasi anggaran yang diterima masing-masing desa tidak sedikit jumlahnya, yang seharusnya menjadi motivasi masyarakat untuk membangun desa. Salah satu permasalahannya adalah desa kekurangan sumber daya aparatur yang kompeten. Berdasarkan penelitian yang dilakukan oleh Aziz (2016), terdapat berbagai hambatan dalam penyaluran dan realisasi dana desa, antara lain rendahnya kapabilitas dan kapasitas sumber daya manusia, dan partisipasi masyarakat desa yang sangat minimal. Hasil kajian menyatakan bahwa desa mengalami krisis SDM yang dianggap sebagai modal sosial untuk mengatur dana desa. Anggaran desa juga belum mencapai persentase sesuai ketentuan peraturan. Hal ini mengindikasikan bahwa petugas desa masih belum mengerti tentang perhitungan realisasi dana desa, terutama pola pembagian pengalokasian dana untuk sebaran penggunaan dana desa yang membutuhkan konsep realisasi dana desa secara masif (Meutia 2017). Sejalan dengan hasil kajian Mardiana (2017), terdapat ketidaksesuaian antara biaya yang dianggarkan melebihi realisasinya, akibatnya program-program kegiatan tidak tercapai sesuai dengan yang dianggarkan. Ditegaskan dalam kajian Jamaluddin (2020) bahwa kebijakan dana desa sebagian besar ditentukan oleh faktor politik dan komitmen para pelaku kebijakan, tidak tergantung pada program yang dikelola dengan baik. Artinya bahwa pengelolaan dana desa menjadi masalah baru ketika dikelola dan dialokasikan tidak sesuai dengan pertaturan yang berlaku.

Peraturan Menteri No. 16 Tahun 2018 yang diterbitkan oleh Menteri Desa, Pembangunan Daerah Tertinggal, dan Transmigrasi Republik Indonesia menjelaskan bahwa penggunaan dana desa diprioritaskan untuk membiayai pelaksanaan program dan kegiatan di bidang pembangunan desa dan pemberdayaan masyarakat desa. Prioritas penggunaan dana desa dapat digunakan untuk membiayai pelaksanaan program dan kegiatan prioritas yang bersifat lintas bidang, yang diharapkan dapat memberikan manfaat sebesar-besarnya bagi masyarakat desa berupa peningkatan kualitas hidup, peningkatan kesejahteraan dan penanggulangan kemiskinan serta peningkatan pelayanan publik di tingkat Desa (BPK 2018). Berdasarkan isi peraturan tersebut, dapat diketahui bahwa penggunaan anggaran desa harus dilakukan dengan berbagai pertimbangan. Pengaturan anggaran desa harus berdasarkan ketentuan yang baku untuk menciptakan manajemen anggaran yang akuntabel, yang tentunya melalui sistem akuntansi langsung dan tepat sasaran dengan memperhatikan komposisi alokasi anggaran yang tertuju pada perencanaan program yang matang dan berfokus pada perbaikan sarana prasarana serta peningkatan kualitas SDM, dan sasaran anggaran dapat berkolaborasi antar unit di dalam lingkungan desa (misalnya digunakan pada unit pelayanan masyarakat atau dimanfaatkan dalam bidang sosial).

Perumusan masalah dalam kajian ini adalah bagaimana membuat skala kebutuhan desa yang berkenaan dengan penggunaan anggaran sesuai dengan Peraturan Pemerintah No. 60 Tahun 2014 tentang Dana Desa di Kabupaten Semarang, Demak, dan Kendal. Permasalahan yang terjadi di lokus penelitian ini adalah indikasi adanya intervensi kepala daerah dalam penggunaan anggaran dana desa dan ketidakpahaman pengelola dalam merealisasikan dana desa. Oleh karena itu, kajian ini akan membuat strategi untuk menciptakan manajemen anggaran desa yang akuntabel dan transparan. Strategi ini dipandang untuk membentuk solusi agar tidak terjadi kesalahan baik dalam hal pola pikir maupun manajemen anggaran desa. Tujuan kajiannya adalah untuk mengidentifikasi 
kebutuhan desa sesuai dengan Peraturan Pemerintah No. 60 Tahun 2014 tentang Dana Desa yang berbunyi bahwa dana yang bersumber dari Anggaran Pendapatan dan Belanja Negara yang diperuntukkan bagi Desa yang ditransfer melalui Anggaran Pendapatan Belanja Daerah kabupaten/kota dan digunakan untuk mendanai penyelenggaraan, pelaksanaan pembangunan, pembinaan kemasyarakatan, dan pemberdayaan masyarakat (BPK 2014). Kajian ini akan mengangkat bagaimana memperhitungkan kebutuhan utama dalam melakukan penyerapan dana desa sesuai dengan yang tertulis dalam regulasi. Kajian Antityasputri (2019) mengungkapkan bahwa dana desa memiliki potensi untuk meningkatkan kualitas hidup masyarakat.

\section{METODE}

Penelitian ini menggunakan pendekatan kualitatif. Waktu pelaksanaan kajian pada bulan April tahun 2015 dengan lokus kajian diambil 3 desa dari tiap-tiap kabupaten. Lokasi kajian dipilih secara pusposive sampling berdasarkan kabupaten yang memiliki desa dengan serapan dana desa tertinggi, sedang dan rendah. Pemilihan lokasi kabupaten berkonsultasi dengan pemerintah propinsi yang lebih mengetahui kondisi di wilayahnya.Pada Kabupaten Semarang diwakili desa Leyangan, Kalongan dan Jati Jajar; Kabupaten Kendal diwakilkan Kedung Boto, Sarirejo dan Nolokerto dan Kabupaten Demak mengambil daerah Mandung, Babalan dan Kalikondang. Data primer diambil melalui wawancara dengan unsur petugas pelaksana seperti Sekretariat Daerah bagian Pemerintahan Desa, DPPKAD (Dinas Pendapatan Pengelolaan Keuangan dan Aset Daerah), BPMD (Badan Pemberdayaan masyarakat Desa), dan pemerintahan desa yang terdiri dari Kapala Desa, Sekertaris Desa dan Perangkat Desa serta Badan Permusyawaratan Desa. Selain itu juga dilakukan Focus Group Discussion (FGD) dan observasi/pengamatan langsung di lapangan. Pengumpulan data sekunder dilakukan melalui studi pustaka, berupa telaahan terhadap tulisan jurnal, majalah ilmiah, dan hasilhasil penelitian terkait. Data dianalisis sevara deskriptif dan disajikan dalam bentuk mantriks.

\section{HASIL DAN PEMBAHASAN}

\section{Skala Kebutuhan dan Realisasi Desa yang Berkenaan dengan Penggunaan Anggaran}

Berkaitan dengan penyerapan anggaran desa di kabupaten Semarang khususnya pada daerah target kajian merujuk kepada Permenkeu Nomor 93/PMK.07/2015 tentang Tata Cara Pengalokasian, Penyaluran, Penggunaan, Pemantauan, dan Evaluasi Dana Desa. Pasal 21 hingga pasal 25 yang menyatakan bahwa dana desa digunakan untuk membiayai penyelenggaraan pemerintahan, pembangunan, pemberdayaan masyarakat, dan kemasyarakatan. Dana desa diprioritaskan untuk membiayai pembangunan dan pemberdayaan masyarakat sesuai dengan prioritas penggunaan dana desa yang ditetapkan oleh Menteri Desa, Pembangunan Daerah Tertinggal dan Transmigrasi (Kemenkeu 2016).

Berdasarkan ketentuan yang telah dijabarkan di atas tentang prioritas penggunaan dana desa yang telah ditetapkan, maka Kabupaten Semarang pada tahap pencairan pertama dan kedua diarahkan untuk pada belanja modal baik untuk Desa Leyangan, Kalongan dan Jatijajar (Tabel 1). Klasifikasi prioritas penggunaan anggaran di Desa Leyangan Kabupaten Semarang dikhususkan untuk pembangunan infrastruktur, sedangkan di Desa Kalongan penggunaan anggaran dipergunakan untuk pembenahan infrastruktur berupa pembangunan prasarana fisik, dan di Desa Jatijajar penggunaan dana desanya digunakan untuk penyelenggaraan pemerintahan desa berupa instalasi gedung PAUD, membuat sumber air yang dapat dikonsumsi masyarakat, perawatan jalan, dan pembangunan gorong-gorong. 
Tabel 1. Jenis Belanja dan Prioritas Peruntukan Anggaran Desa untuk Tahap I, II dan III Desa Leyangan, Kalongan dan Jatijajar Kabupaten Semarang Tahun 2015

\begin{tabular}{lcclcc}
\hline No. & Desa & Jenis Belanja & \multicolumn{1}{c}{$\begin{array}{c}\text { Prioritas } \\
\text { Peruntukan }\end{array}$} & Persentase (\%) & Keterangan \\
\hline 1. & Leyangan & Modal & $\begin{array}{l}\text { Pelaksanaan } \\
\text { Pembangunan Desa }\end{array}$ & 100 & Tahap 1 dan 2 \\
\hline 2. & Kalongan & Modal & $\begin{array}{l}\text { Pelaksanaan } \\
\text { Pembangunan Desa }\end{array}$ & 100 & Tahap 1 dan 2 \\
\hline 3. & Jatijajar & Modal & $\begin{array}{l}\text { Penyelenggaraan } \\
\text { Pemerintahan Desa }\end{array}$ & 100 & Tahap 1 d an 2
\end{tabular}

Sumber: data primer yang diolah (2015)

Pengelolaan dana desa di 3 desa Kabupaten Demak, yaitu Desa Mandung, Desa Babalan dan Desa Kalikondang Kabupaten Demak, diidentifikasi sudah dua kali dicairkan dengan rincian pada Tabel 2.

Tabel 2. Jenis Belanja Desa dan Prioritas Realisasi Anggaran Desa Termin I dan Termin II di Desa Mandung, Babalan dan Kalikondang Kabupaten Demak Tahun 2015

\begin{tabular}{llllcl}
\hline No. & Desa & Jenis Belanja & Prioritas Peruntukan & Persentase & Keterangan \\
\hline 1. & Mandung & Belanja Pegawai & Pelaksanaan & 100 & Termin 1 dan \\
& & & Pembangunan Desa & & 2 \\
\hline 2. & Babalan & Belanja Pegawai & Pelaksanaan & 100 & Termin 1 dan \\
& & & Pembangunan Desa & & 2 \\
\hline 3. & Kalikondang & Belanja Pegawai & Pelaksanaan & 100 & Termin 1 dan \\
& & & Pembangunan Desa & & 2 \\
\hline
\end{tabular}

Sumber: data primer yang diolah (2015)

Pengelolaan dana desa di Desa Mandung, Desa Babalan dan Desa Kalikondang Kabupaten Demak 100\% digunakan untuk pembangunan fisik sesuai dengan intruksi Bupati yang diatur dalam Permenkeu Nomor 93/PMK.07/2015. Berdasarkan hasil wawancara dengan Kepala Desa Babalan bahwa sudah ada percepatan penyerapan dengan membentuk 3 Tim Pengelola Kegiatan (TPK). Tim ini yang nantinya akan bergerak percepatan pemanfaatan dana desa. Atas dasar tersebut, Kabupaten Demak pada termin pertama dan kedua membangun infrastruktur sebesar 94\% dan pembinaan kemasyarakatan desa sebesar 6\%. Hal ini sesuai dengan arahan keputusan Bupati. Sedangkan pencairan pada termin kedua masih tetap diarahkan untuk pelaksanaan pembangunan desa dengan membangun infrastruktur sebesar $95,1 \%$ dan pembinaan kemasyarakatan desa dengan membangun PAUD 4,9\% sesuai dengan arahan keputusan Bupati.

Pengelolaan dana desa di 3 desa Kabupaten Kendal, yaitu Desa Kedung Boto, Desa Sarirejo, dan Desa Nolokerto diidentifikasi sudah dua kali dicairkan (tabel 3 dan tabel 4). Dana desa yang dicairkan di Termin pertama sebagian besar digunakan untuk mendirikan sarana prasarana. Desa Kedung Boto mempergunakan dana desa pada belanja pegawai sebesar 3,6\% untuk membayar honor Tim Pengendali Keuangan untuk menunjang pelaksanaan pelaporan anggaran desa; 2,2\% untuk perbaikan prasasti, pembelian ATK dan PMT Posyandu; dan 94,2 \% untuk materil sarana prasarana. Desa Sarirejo dan Nolokerto menggunakan dana desanya untuk belanja barang dan jasa sebesar $100 \%$, untuk pembangunan insfrastruktur dan PAUD dilakukan oleh desa Sarirejo dan desa Nolokerto misalnya untuk perbaikan pengerasan jalan, perbaikan makam, saluran irigasi, pengaspalan, perbaikan PAUD serta perbaikan Posyandu dalam meningkatkan pelayanan kepada masyarakat. Pada umumnya. Kabupaten Kendal menggunakan anggarannya sesuai 
dengan arahan Bupati Kendal untuk meningkatkan kinerja dan sebagai wujud terciptanya pemeliharaan pertanggungjawaban laporan.

Tabel 3. Jenis Belanja Desa dan Prioritas Realisasi Anggaran Desa Termin I di Desa Kedung Boto, Desa Sarirejo dan Desa Nolorejo Kabupaten Kendal tahun 2015

\begin{tabular}{clllll}
\hline No. & Desa & Jenis Belanja & $\begin{array}{l}\text { Prioritas } \\
\text { Peruntukan }\end{array}$ & Prosentase & Keterangan \\
\hline 1. & Kedung Boto & Belanja Pegawai & $\begin{array}{l}\text { Pelaksanaan } \\
\text { Pembangunan } \\
\text { Desa }\end{array}$ & 100 & $\begin{array}{l}\text { Honor TPK, } \\
\text { ATK, Prasari, } \\
\text { PMT,Material }\end{array}$ \\
\hline 2. & Sarirejo & Modal & $\begin{array}{l}\text { Pelaksanaan } \\
\text { Pembangunan } \\
\text { Desa }\end{array}$ & 100 & $\begin{array}{l}\text { Infrastruktur } \\
\text { PAUD }\end{array}$ \\
\hline 3. & Nolokerto & Belanja & $\begin{array}{l}\text { Pelaksanaan } \\
\text { Pembangunan } \\
\text { Desa }\end{array}$ & $100 \%$ & Infrastruktur \\
& & Operasional & & \\
\hline
\end{tabular}

Sumber: data primer yang diolah (2015)

Tabel 4. Jenis Belanja Desa dan Prioritas Realisasi Anggaran Desa Termin II di Desa Kedung Boto, Desa Sarirejo dan Desa Nolorejo Kabupaten Kendal tahun 2015

\begin{tabular}{clllll}
\hline No. & Desa & Jenis Belanja & Prioritas Peruntukan & Persentase & Keterangan \\
\hline 1. & Kedung Boto & $\begin{array}{l}\text { Belanja pegawai, } \\
\text { belanja } \\
\text { operasional dan }\end{array}$ & $\begin{array}{l}\text { Pelaksanaan } \\
\text { pembangunan desa }\end{array}$ & 100 & Honor TPK, \\
& & & & ATK, \\
modal & & - & - & Material \\
2. & Sarirejo & - & - & - & - \\
3. & Nolokerto & - & - & - & - \\
\hline
\end{tabular}

Sumber: data primer yang diolah (2015)

Anggaran desa yang sudah diterapkan di tahun 2015 sesuai arahan dan kebijakan Bupati Kendal untuk mendirikan sarana prasarana dan pembinaan kemasyarakatan dengan komposisi tetap di dominasi oleh pembangunan fisik. Komposisi penggunaan dana desa di Desa Kedung Boto adalah honor TPK sebanyak 7,8\%; prasasti sebanyak 0,8\%; dan pembelian material sebanyak 91,4\%. 2 desa lainnya tidak melakukan realisasi anggaran dana desa termin kedua.

Lahirnya penguatan kewenangan desa dalam mengatur wilayahnya, sejatinya memerlukan kesiapan dalam pelaksanaannya. Kesiapan tersebut dimulai dari pemerintah pusat hingga ke level bawah, yaitu pada level desa. Kesiapan tersebut ditujukan agar tidak ada lagi keterlambatan dalam pencairan dana desa tahap pertama di berbagai daerah. Penyaluran dana desa syaratmya hanyalah menyerahkan Peraturan Gubernur (Pergub), Peraturan Walikota (Perwali), dan Peraturan Bupati (Perbup) yang mengacu pada peraturan. Anggaran desa ditransfer dengan alur atau kerangka kerja dari pemerintah pusat ke pemerintah daerah, secara teknis daerah menerima langsung anggaran tersebut tanpa melalui perantara. Kemudahan penyaluran menjadi dilematis dan rentannya akuntabilitas dalam merealisasikan pertanggungjawaban keuangannya. Tuntutan bagi kepala desa untuk bergerak dan mengalihkan anggaran menjadi kegiatan yang dapat dibuktikan dengan kegiatan riil dan dapat diakses masyarakat sebagai unsur pemantauan. Adapun total anggaran yang diterima oleh Desa di Kabupaten Semarang, Demak dan Kendal disajikan dalam Tabel 5. 
Tabel 5. Total Dana Desa Kabupaten Semarang, Demak dan Kendal Tahun 2015

\begin{tabular}{lll}
\hline No. & Kabupaten & Besaran $($ Rp) \\
\hline 1. & Semarang & $57.840 .951 .000,-$ \\
2. & Demak & $73.852 .743 .000,-$ \\
3. & Kendal & $74.239 .102 .000,-$ \\
\hline
\end{tabular}

Sumber: Data primer yang diolah (2015)

Berdasarkan besaran yang diberikan kepada Kabupaten Semarang, Demak dan Kendal menunjukkan nilai yang berbeda hal ini berdasarkan pengalokasian anggaran dihitung berdasarkan kondisi demografi desa. Untuk penggunaan anggaran telah diatur di dalam regulasi desa terkait bagaimana pemakaian anggaran yang sebenarnya, contohnya anggaran akan diarahkan pada pengembangan akses penghubung ke desa atau ingin membangun kapasitas pemuda di desa, dan sebagainya. Ketentuan dalam penyerapan rencana anggaran belanja tertuang dalam Permendes dan PDTT nomor 5 tahun 2014. Fokus untuk pemanfaatan bisa digunakan oleh individu maupun kelompok masyarakat. Intinya pertanggungjawaban secara realitas dapat dinilai kebenarannya. Jenis belanja desa dan peralihan anggaran dapat dilihat pada tabel 6 .

Tabel 6. Belanja desa dan prioritas pemberian anggaran termin 1 dan termin II di Kabupaten Semarang, Demak dan Kendal Tahun 2015

\begin{tabular}{cllll}
\hline No. & Jenis Belanja & Prioritas Peruntukan & Prosentase & Keterangan \\
\hline 1. & Semarang & Belanja operasional, modal & 100 & $\begin{array}{l}\text { Pelaksanaan } \\
\text { Pembangunan Desa } \\
\text { 2. }\end{array}$ \\
Demak & Belanja operasional & 100 & $\begin{array}{l}\text { Pelaksanaan } \\
\text { Pembangunan Desa }\end{array}$ \\
3. & Kendal & Modal & 94 & $\begin{array}{l}\text { Pelaksanaan } \\
\text { Pembangunan Desa }\end{array}$ \\
\hline
\end{tabular}

Sumber: Data diolah Desember 2015

Dana desa di Kabupaten Semarang dan Demak dipergunakan untuk pembayaran SDM, belanja operasional, dan belanja modal. Sedangkan di Kabupaten Kendal dana desa di termin pertama dimanfaatkan untuk pembangunan infrastruktur dan pembangunan PAUD. Pemanfaatan anggaran di Kabupaten Semarang dipergunakan berdasarkan prioritas yang telah ditetapkan pada Permendes dan PDTT Nomor 5 Tahun 2014 tentang Prioritas Penggunaan Dana Desa. Menurut hasil penelitian yang dilakukan Salindeho (2017), pengelolaan dana desa sepenuhnya diserahkan kepada desa, termasuk perencanaan prioritas. Desa berhak menentukan skala prioritas sesuai dengan kebutuhan masyarakat paling tahu apa yang dibutuhkan oleh desa tersebut.

Permasalahan yang ditemui dalam penggunaan dana desa di Kabupaten Semarang adalah adanya keraguan dalam penentuan prioritas. Pembinaan dan pemberdayaan organisasi desa seperti PKK dan Karang Taruna masuk seharusnya masuk pada lingkup kegiatan pemberdayaan, namun pada pelaksanaannya masuk pada kegiatan dengan ruang lingkup kemasyarakatan. Realisasi anggaran lebih diprioritaskan ke kegiatan pembangunan fisik di desa. Sedangkan untuk kegiatan pemerintahan dan kemasyarakatan yang didanai Alokasi Dana Desa (ADD) nilainya relatif sedikit. Solusi dalam permasalahan pengelolaan dan realisasi anggaran adalah yang penentuan program prioritas dan perlunya penyusunan tahapan cadangan pemanfaatan berdasarkan petunjuk dari pemerintah pusat tentang penggunaan akun-akun cadangan, misalnya untuk pembangunan kantor atau balai desa yang kegiatannya simultan tahunan. Oleh karena itu sangat penting untuk melakukan penyamaan persepsi dalam penggunaan dana desa untuk kemasyarakatan dan kegiatan di luar realisasi.

Pengggunaan dana desa di Kabupaten Kendal pada Termin I dan II telah sesuai dengan arahan keputusan Bupati. Pada termin pertama, dana direalisasikan untuk mendirikan gedung dan PAUD. Penggunaan dana termin kedua menunjukan bahwa 
capaian pertanggungjawaban anggaran baik Kabupaten Semarang, Demak dan Kendal masih pada belanja barang, jasa, dan belanja modal. Sedangkan untuk klasifikasi belanja operasional sebagian besar dialihkan pada terbentuknya pembenahan jalan, gedung, dan sebagainya. Hanya di Kabupaten Demak yang menggunakan dana desa untuk kegiatan penyelenggaraan pemerintahan desa, pelaksanaan pembangunan desa, pembinaan kemasyarakatan, dan pemberdayaan masyarakat desa. Sedangkan realisasi dana desa termin II di Kabupaten Kendal masih sesuai dengan arahan Bupati..

Realisasi anggaran desa pada daerah lokus dalam pelaksanaannya disesuaikan dengan skala prioritas. Menurut Ant (2018), Tjahjo Kumolo menegaskan bahwa 30\% alokasi dana desa diperuntukkan bagi pemberdayaan masyarakat setempat. Hal ini mengindikasikan adanya peluang bagi masyarakat untuk meningkatkan kompetensinya. Pernyataan ini sesuai dengan kajian Matridi (2015) bahwa pemerintah tidak harus mengintervensi kepentingan semua aktivitas yang diajukan oleh penduduk desa. Begitu pula dalam dana desa, partisipasi masyarakat sangat penting dalam menentukan kebutuhan programnya. Nastiti (2014) memperkuat pernyataan tersebut bahwa ketika dana desa saudah dapat dicairkan, $70 \%$ harus digunakan untuk masyarakat, sedangkan sisanya $30 \%$ boleh untuk gaji aparat desa atau kepentingan SDM lainnya. Oleh karena itu, anggaran desa harus diprioritaskan untuk membiayai kegiatan sesuai kewenangan dan pada skala desa yang meliputi kegiatan-kegiatan yang peruntukkannya demi kemajuan desa. Menurut Eko (2018), pada tahun 2019 dana desa diprioritaskan pada pembentukan SDM dan pemberdayaan ekonomi desa. Program ini diarahkan untuk memandirikan desa dengan anggaran yang telah diperoleh untuk membangun. Akan tetap, pernyataan ini sangat menarik, faktanya tiga tahun terakhir dana desa lebih banyak untuk bidang pembangunan infrastruktur publik desa yang berkisar $83 \%-87 \%$, sedangkan untuk bidang pemberdayaan hanya berkisar 7\%-12\%. Ubaidi menambahkan "ada penegasan untuk memberikan porsi pada setiap desa. Persentase itu berdasarkan data realisasi pemakaian anggaran tahun 20152017 (Azka 2018).

Perubahan pemakaian anggaran yang telah disebutkan di atas, lebih lanjut akan mengarah pada peningkatan perekonomian desa melalui optimalisasi usaha mikro di desa, pelatihan kompetensi aparatur dan penciptaan laporan yang akuntabel (Azka 2018). Penataan pembagian anggaran desa di tahun 2019 dilakukan dengan empat tahap yaitu kategori desa yang mendapatkan Rp. 600 juta-Rp. 800 juta sebanyak 26.027 desa, kategori Rp. 800 juta-Rp1 miliar sebanyak 29.347 desa, kategori Rp1 miliar-Rp1,2 miliar sebanyak 10.127 desa, dan di atas Rp1,2 miliar sebanyak 9.452 desa. Total desa yang mendapatkan dana desa sebanyak 74.953 desa. Kategori tersebut didasarkan pada perhitungan alokasi dasar, afirmasi yang memperhatikan kategori desa tertinggal dan desa sangat tertinggal, serta alokasi formula yang di antaranya memperhitungkan jumlah penduduk, penduduk miskin, dan luas wilayah. Indikator keberhasilan dana desa tersebut, di antaranya Rasio Gini (RG) perdesaan yang menurun dari 0,34 pada 2014 menjadi 0,32 pada 2018, sedangkan jumlah penduduk miskin desa menurun menjadi 15,81 juta pada 2018 sementara pada 2014 sebanyak 17,37 juta jiwa. Sejumlah pembangunan fisik pun tercatat sebagai hasil penggunaan dana desa sepanjang 2015-semester I/2018, di antaranya pembangunan jalan desa 158.619 km, fasilitas Mandi Cuci Kakus (MCK) 177.991 unit, embung sebanyak 3.026 unit, dan posyandu sebanyak 18.476 unit (Azka 2018).

Peraturan Pemerintah Nomor 60 Tahun 2014 tentang Dana Desa dan Peraturan Menteri Dalam Negeri Nomor 20 Tahun 2018 tentang Pengelolaan Keuangan Desa telah menyebutkan keseimbangan realisasi dana desa. Akan tetapi terdapat beberapa ketidaksesuaian antara regulasi dengan implementasi di lokus penelitian. Di Semarang, alokasi belanja barang dan jasa dari anggaran desa sebesar 20\%, dan belanja modal $80 \%$. Sedangkan Kabupaten Kendal dan Kabupaten Demak mengalokasikan 100\% anggaran desa untuk pembangunan fisik. Seharusnya prioritas peruntukan anggaran desa adalah pada aspek perbaikan infrastruktur dan pembenahan kualitas SDM. Seiiring dengan hasil penelitian yang dilakukan oleh Gunawan (2019), pengelolaan dana desa belum 
dilaksanakan secara efektif dan efisien. Pelaksanaan dan pembangunan desa tidak dilaksanakan sesuai perencanaan yang dilakukan. Hal ini juga diperkuat oleh kajian dari Wisra (2019), bahwa pengelolaan dana desa belum optimal dikarenakan kurangnya pelibatan masyarakat dalam perencanaan. Mengambil contoh dari hasil penelitian Noviyanti (2018), penentuan prioritas di Desa Bulutengger disepakati dan diputuskan melalui musyawarah desa, serta dipublikasikan kepada masyarakat oleh aparat pemerintah desa di Balai Desa Bulutengger.

Mengingat pembangunan fisik masih lebih dominan, maka diperlukan adanya sebuah strategi yang tepat untuk bagaimana mengatur dana desa secara akuntabel. Berdasarkan kondisi di lapangan, maka rekomendasi strategi yang bisa dilakukan adalah: (1) Penggunaan dana desa untuk inovasi desa dann disesuaikan dengan potensi desa; (2) Konsumsi dana desa untuk pengembangan masyarakat melalui pembangunan kapasitas masyarakat agar berdaya guna. Hal ini penting mengingat tidak efektifnya pemanfaatan dana desa salah satunya diakibatkan oleh kurang pedulinya masyarakat desa. Peran masyarakat di internal desa perlu untuk digalakkan, terutama SDM yang masih produktif agar dapat membangkitkan keinginan berusaha. Menurut Hariansyah (2018), angkatan kerja produktif harus diberikan kepercayaan untuk mengelola Badan Usaha Milik Desa (BUMDes), SDM produktif diharapkan dapat mengelola BUMdes secara sistematis dan terstruktur, serta tidakterpengaruh dengan kepentingan-kepentingan tertentu sehingga pengelolaan BUMdes akan jauh dari hal-hal yang bersifat politik. SDM produktif biasanya memiliki strata pendidikan yang cukup tinggi, sehingga berpengaruh dalam menilai kebutuhan desanya; (3) Penggunaan dana desa untuk kegiatan pembangunan fisik dan pembangunan non fisik yang meliputi kegiatan pengembangan dan pembinaan SDM seperti pengembangan usaha ekonomi produktif dan pelestarian lingkungan hidup; dan (4) Manajemen dana desa untuk pengembangan kapasitas pemerintahan desa. Menurut Soelasno (2016), sosalisasi tentang pengelolaan dana desa belum tersampaikan dengan benar. Oleh karena itu diperlukan pelatihan SDM pengelola dana desa.

Beberapa temuan lapangan yang dapat diidentifikasi yaitu (1) Kuatnya intervensi kepala daerah dalam mengatur dana desa. Kabupaten Kendal menyesuaikan penggunaan dana desa dengan instruksi Bupati Kendal, yaitu 95,1\% untuk pembangunan infrastruktur dan dan 4,9\% membentuk lembaga desa (pembangunan PAUD); (2) Ketidakpahaman masyarakat maupun para pemerintahan desa di lokus penelitian dalam menterjemahkan dana desa. Dana desa dipandang sebagai anggaran utama untuk pembangunan fisik. Anggapan ini sangat berseberangan dengan konsep dalam regulasi, bahwa membangun desa melalui konteks perubahan infrastruktur dan perubahan kualitas manusia.

\section{SIMPULAN DAN REKOMENDASI}

\section{Simpulan}

Skala prioritas penggunaan dana desa di Kabupaten Semarang diarahkan untuk pembangunan fisik sesuai Permenkeu Nomor 93/PMK.07/2015 tentang Tata Cara Pengalokasian, Penyaluran, Penggunaan, Pemantauan, dan Evaluasi Dana Desa; skala prioritas di Kabupaten Demak digunakan untuk ASN dan masyarakat sesuai dengan instruksi kepala daerah; sedangkan skala prioritas Kabupaten Kendal adalah melakukan perubahan fisik dan non fisik sesuai dengan instruksi kepala daerah. Ketiga daerah ini memiliki perbedaan dalam mengalokasikan dana desa dan pengelolaannya. Oleh karena itu, seharusnya pemanfaatan dana desa diputuskan melalui musyawarah dengan tetap mempertimbangkan arahan dari kepala daerah.

\section{Rekomendasi}

Berdasarkan hasil penelitian, maka rekomendasi yang dapat dilakukan adalah: (1) Identifikasi kebutuhan desa berdasarkan pemetaan masalah yang ada di daerah tersebut; (2) Melakukan pengawasan untuk mensinkronkan APBDesa dengan skala prioritas 
penggunaan dana desa sekaligus menindaklanjuti hasil laporan pengawasan tersebut; dan

(3) Melibatkan kader desa untuk menjadi tim pengawas dana desa dan kesesuaian usulan pemanfaatan dana dengan skala prioritas.

\section{UCAPAN TERIMA KASIH}

Kajian ini merupakan karya terakhir dari almarhum Bapak Arief Sulasdiono. Karya ini adalah harapan beliau untuk dipublikasikan pada jurnal sebelum menghembuskan nafas terakhir. Terima kasih apabila karya ini dapat dipublikasikan oleh redaksi yang memuatnya, serta ucapan kepada tim kajian yang membantu. Termasuk adalah Ray Septianis Kartika sebagai kontributor anggota yang merampungkan karya ini sebagai sebuah kenang-kenangan. Semoga bermanfaat dan menjadi kebaikan buat kita semua.

\section{DAFTAR PUSTAKA}

Ant. 2018. "Mendagri: 30 persen Dana Desa untuk Berdayakan Masyarakat." Okenews. $\begin{array}{lllll}\text { Februari 20. Accessed } 2020 . & \text { September }\end{array}$ https://news.okezone.com/read/2018/02/20/340/1861954/mendagri-30-persendana-desa-untuk-berdayakan-masyarakat.

Antityasputri. 2019. "Analisis Implementasi Pengelolaan Dana Desa Menggunakan Aplikasi Siskeudes Desa Banyuanyar." Perspektif Akutansi Vol 2 Nomor 2: 169193. Accessed Januari 17, 2021. doi:https://doi.org/10.24246/persi.v1i2.p169-193.

Azka, Rinaldi Mohammad. 2018. "Pemanfaatan Daan Desa akan Bergeser ke Pembangunan Manusia." Desember 10. Accessed September 24, 2020. https://ekonomi.bisnis.com/read/20181210/9/868044/pemanfaatan-dana-desaakan-bergeser-ke-pembangunan-manusia.

Berdesa. 2018. "Prioritas Penggunaan Dana Desa Tahun 2019 Menurut Permen No.16 Tahun 2018." Accessed September 3, 2020. http://www.berdesa.com/prioritaspenggunaan-dana-desa-tahun-2019-menurut-permen-no-16-tahun-2018/.

Eko. 2018. "Dana Desa 2019 Diproritaskan untuk Pemberdayaan Masyarakat." Antara News. November 5. Accessed September 23, 2020. https://www.antaranews.com/berita/765306/dana-desa-2019-diprioritaskanuntuk-pemberdayaan-masyarakat.

Gunawan. 2019. "Pengawasan Implementasi Dana Desa di Kabupaten Serdang Bedagai, Provinsi Sumatera Utara." Jurnal Kebijakan Pembangunan Vol 14 Nomor 1 $\begin{array}{lllll}\text { Oktober : 99-107. Accessed } & \text { Februari } 15 & \end{array}$ http://jkpjournal.kalselprov.go.id/index.php/menu/article/view/11/2.

Hariansyah, M. 2018. "Ayo Kawal Dana Desa." Persoalan Dana Desa dan Pentingnya Partisipasi Pemuda. Februari 12. Accessed September 20, 2020. http://youthproactive.com/201802/speak-up/masalah-dana-desa-dan-peranpemuda/.

Jamaluddin, Yanhar. 2020. "Suistainability of Indonesian Village Funds Policies, International." Journal of Advance Science and Technology Vol. 29 (10) 29662973.

Kemenko Bidang PMK. 2018. Peningkatan Kualitas Penggunaan dana Desa. Jakarta: Kemenko Bidang PMK.

Li, T.M. 2016. "Governing Rural Indonesia:Convergence on the Project System." Critical Policy Studies Vol 10 Nomor 1: 79-94. Accessed September 24, 2020. doi:https://doi.org/10.1080/19460171.2015.1098553. 
Mardiana. 2017. "Analisis Anggaran dan Realisasi Dana Desa pada Desa Epil Kecamatan Lais Kabupaten Musi Banyuasin." Jurnal Riset Terapan Akuntansi Vol. 1 No.1 3542.

Matridi, Abumanshur, Zuraidi, and Dedi. 2015. "An Evaluation of P3DK (An Acceleration of Development Village Program): A Reviewing on Failure Toward Revolving Loan Fund System in Kepulauan Riau Province, Indonesia." Procedia-Social and Behavioral Sciences Vol 169, 20 Januari : 189-197. doi:https://doi.org/10.1016/j.sbspro.2015.01.302.

Meutia, Inten. 2017. "Pengelolaan Keuangan Dana Desa." Jurnal Akutansi $\begin{array}{lllll}\text { Multiparadigma } & \text { Vo.8 } & \text { No. } & 2: & 336-352 .\end{array}$ http://dx.doi.org/10.18202/jamal.2017.08.7058.

N.L.L, Aziz. 2016. "Otonomi Desa dan Efektivitas Dana Desa." Jurnal Penelitian Politik Vol 13 Nomor 2: 193-211. Accessed September 17, 2020. doi:https://doi.org/10.14203/jpp.v13i2.575.

Nastiti, Pamuji Tri. 2014. "UU DESA: 70\% Anggaran untuk Masyarakat \& 30\% untuk Aparat Desa." Ekonomi. Edited by Sepudin Zuhri. November 15. Accessed Desember 3, 2020. https://ekonomi.bisnis.com/read/20141115/9/273184/uu-desa70-anggaran-untuk-masyarakat-30-untuk-aparat-desa.

Noviyanti. 2018. "Pengidentifikasian Pendapatan dan Prioritas Penggunaan Dana Desa." Publisia: Jurnal Ilmu Administrasi Publik Vol 3 Nomor 2 Oktober: 112-120. $\begin{array}{llll}\text { Accessed } & \text { Februari 20, }\end{array}$ http://jurnal.unmer.ac.id/index.php/jkpp/article/view/2378/pdf.

Sulasdiono, Arief. 2015. Laporan Kajian Implementasi Pengelolaa Dana Desa di Provinsi Jawa Tengah. Laporan Penelitian, Badan Penelitian dan Pengembangan Kemendagri. Accessed Desember 1, 2020.

UGM. 2016. Dana Desa Kapasitas Aparatur Desa Harus Ditingkatkan. Accessed Desember 24, 2020. https://cpps.ugm.ac.id/dana-desa-kapasitas-aparatur-desaharus-ditingkatkan/.

Wisra. 2019. "Implementasi Pengelolaan Dana Desa Bidang Pemberdayaan Masyarakat di Tengah Gejolak Turbulensi Keuangan Desa." Jurnal UIN Jakarta 87-94. https://id.elsevier.com/as/8IIa5/resume/as/authorization.ping?client_id=OSCV1\&state=login-602a09b6ed34a7.00428603. 